DOI 10.22363/2618-897X-2021-18-1-6-19

Research Article

\title{
Omnilingual Aspirations: The Case of the Universal Declaration of Human Rights
}

\author{
S.G. Kellman \\ University of Texas at San Antonio, USA \\ 1 UTSA Circle, San Antonio, TX 78249
}

\begin{abstract}
Adopted by the United Nations in 1948, the Universal Declaration of Human Rights is, according to the Guinness Book of World Records, the most widely translated document. However, versions in 419 languages are not conceived as translations but equivalences, alternate embodiments of identical tenets. The Bible has been rendered into numerous languages, but the Hebrew and Greek originals possess authority that English, Bengali, and Xhosa derivatives do not. The Bible is translated, but the UDHR is, through the theology of international governance, transubstantiated into multiple tongues. No version has priority; each is equally valid, transparent, and interchangeable. The utopian premise is not only that all humans possess inalienable rights but also that all languages express the same principles. The document's title, the Universal Declaration of Human Rights, might seem a solecism, a misplaced modifier. Surely, it is human rights that are universal, not the declaration. However, the UN insists that all versions (at least in the original official languages) are equally binding. It rejects Whorfian notions that particular languages enable particular thoughts and embraces languages as neutral tools whose specific manifestation is irrelevant. Arguments against imprisoning writers in Burma could appeal equally to the authority of either the Universal Declaration of Human Rights or la Déclaration universelle des droits de l'homme or Всеобщую декларацию прав человека or la Declaración Universal de Derechos Humanos or 世界人权宣言. Rather than the Babelian myth of an Ur-Sprache before hubris scattered us into mutual unintelligibility, the UDHR endorses a Chomskyan belief that all languages can express the same thoughts. Yet differences among versions of Article 1 ("All human beings are born free and equal in dignity and rights") are not trivial; dignity is incommensurable with Würde, $\alpha \xi 10 \pi \rho \varepsilon ́ \pi \varepsilon 1 \alpha$, dignidade, waardigheid, or достоинства. The UDHR is a translingual text shaped by the languages of framers and translators.
\end{abstract}

Key words: translingualism, the Universal Declaration of Human Rights, translation, equivalence

\section{Article history:}

Received: 17.10 .2020

Accepted: 14.12.2020

Moderator: O.A. Valikova

(C) Kellman S.G., 2021

This work is licensed under a Creative Commons Attribution 4.0 International License https://creativecommons.org/licenses/by/4.0/ 


\title{
Conflict of interests: none
}

\section{For citation:}

Kellman, S.G. 2021. "Omnilingual Aspirations: The Case of the Universal Declaration of Human Rights". Polylinguality and Transcultural Practices, 18 (1), 6-19. DOI 10.22363/2618-897X2021-18-1-6-19

\section{Всеязычные устремления: на примере Всеобщей декларации прав человека}

\author{
С.Г. Келлман \\ Техасский университет Сан-Антонио, США \\ 1 Университетский округ, ТХ 78249
}

\begin{abstract}
Аннотация. Всеобщая декларация прав человека, принятая Организацией Объединенных Наций в 1948 году, согласно Книге рекордов Гиннеса, является наиболее переводимым документом в мире. Однако версии на 419 языках задуманы не как переводы, а как эквиваленты, альтернативные варианты идентичных принципов. Библия переведена на множество языков, но древнееврейский и греческий оригиналы обладают авторитетом, а производные от английского, бенгальского и коса - нет. Через теологию международного управления Всеобщая декларация прав человека транслируется на многие языки. Ни одна версия не имеет приоритета; все одинаково актуальны, прозрачны и взаимозаменяемы. Утопический посыл состоит в этом случае не столько в том, что все люди обладают неотъемлемыми правами, сколько в том, что все языки выражают одни и те же принципы. Название документа - Всеобщая декларация прав человека - может показаться солецизмом, неуместным модификатором: универсальны права человека, а не декларация. Однако ООН настаивает на том, чтобы все версии (по крайней мере, на официальных языках оригинала) имели одинаковую обязательную силу. ООН отвергает уорфианские представления о том, что определенные языки конструируют определенные мысли, и принимает языки как нейтральные инструменты, конкретное проявление которых не имеет значения. Аргументы против заключения в тюрьму писателей в Бирме могут в равной степени апеллировать к авторитету the Universal Declaration of Human Rights, la Déclaration universelle des droits de l'homme, Всеобщей декларации прав человека, la Declaración Universal de Derechos Humanos или 世界人权宣言. Словно альтернатива вавилонскому мифу о том, как высокомерие привело человечество к взаимонепонятости, Всеобщая декларация прав человека поддерживает веру Хомского в том, что все языки могут выражать одни и те же мысли. И все же различия между версиями статьи 1 («Все люди рождаются свободными и равными в своем достоинстве и правах») нетривиальны; понятие dignity несоизмеримо с Würde, $\alpha \xi ı \pi \rho \varepsilon ́ \pi \varepsilon ı \alpha$, dignidade, waardigheid или достоинством. Всеобщая декларация прав человека - это транслингвальный текст, созданный на языках разработчиков и переводчиков.
\end{abstract}

Ключевые слова: транслингвизм, Всеобщая декларация прав человека, перевод, эквивалентность 


\section{История статьи:}

Дата поступления в редакцию: 17.10.2020

Дата принятия к печати: 14.12.2020

Модератор: О.А. Валикова

Конфликт интересов: отсутствует

\section{Для цитирования:}

Келлман С.Г. Всеязычные устремления: на примере Всеобщей декларации прав человека // Полилингвиальность и транскультурные практики. 2021. Т. 18. № 1. С. 6-19. DOI 10.22363/2618-897Х-2021-18-1-6-19

\section{Introduction}

In Book I of The Republic, Socrates makes a mockery of Thrasymachus's cynical contention that: "Justice is what is advantageous to the stronger". However, history, written by the conquerors, too often corroborates the claim. While the conclusion to World War II did not necessarily demonstrate that might makes right, it did provide the mighty an opportunity to make rights. The victorious powers that convened in San Francisco in 1945 to create the United Nations declared, in the Preamble to its Charter, that one of the new organization's principal objectives was "to reaffirm faith in fundamental human rights, in the dignity and worth of the human person, in the equal rights of men and women and of nations large and small." It was not until more than three years later, after painstaking deliberations and negotiations among its then 58 members, that the UN got around to enumerating and defining those fundamental human rights, in a document titled the Universal Declaration of Human Rights.

The UDHR is, according to the Guinness Book of Records, "the most translated document" in the world. It can be read in 523 distinct linguistic iterations, in languages ranging from Abkhaz to Zulu. However, these versions are not conceived as translations but rather as equivalences, alternate embodiments of identical tenets. The Bible has been translated in part into 2,123 languages, as a whole into 349. However, in the case of the Bible, unlike the UDHR, it is meaningful to distinguish between the original and its derivatives. The Hebrew and Greek texts possess authority that English, Bengali, and Xhosa approximations do not. Nevertheless, although the Bible is translated, the UDHR is, through the theology of international governance, transubstantiated into multiple tongues. No version has priority; none is the Ur-text. In principle, each is equally valid, transparent, and interchangeable. The utopian - and moot - premise is not only that all humans possess inalienable rights but also that all languages are capable of expressing the same set of fundamental propositions.

The Preamble to the UDHR proclaims that the Declaration provides "a common standard of achievement for all peoples and all nations". That standard is presumed to be the same whether expressed in Igbo, Korean, Quechua, Sanskrit, Welsh, Yiddish, or any of 517 other languages. In its English form, Article 5 proclaims that: "No one shall be subjected to torture, or to cruel, inhuman, degrading treatment or punishment". But it is difficult enough within an exclusively Anglophone legal system to define the term "torture" and determine whether it applies, for example, to waterboarding. The difficulty 
is compounded when torture, which is prohibited by Article 5 of the UDHR, competes with torturas (Spanish), עינויים (inuyim, Hebrew), Folter (German), пытка (pytki,

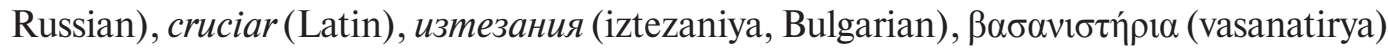
(Greek), and marteling (Afrikaans) as the common standard of cruelty for all peoples and all nations. The UDHR was conceived and created in the aftermath of atrocity, when it became urgent for people of good will to do something decisive to prevent the recurrence of genocide and global mayhem. The Preamble evokes the enormity of the horrors perpetrated under the Nazi régime, the "barbarous acts which have outraged the conscience of mankind", as the motive for devising the Declaration. To the delegates of the United Nations General Assembly meeting temporarily in 1948 in the Palais de Chaillot in Paris - a city that had only three years earlier been liberated from German occupation the Rape of Nanking, the conscription of Korean "comfort women", and the brutal war in the Pacific seemed less compelling than the reversion of European civilization to savagery. But whatever the impetus, the leaders of the world found it imperative to enumerate and affirm the inalienable rights possessed by all human beings of all eras and all cultures. Because uniformity of phrasing was less crucial than universal promulgation, the United Nations insisted that "no distinction" be made "between languages and dialects since all of them serve the purpose of global dissemination".

The UN actively encourages the creation of additional linguistic versions of the UDHR: "to the end that every individual and every organ of society, keeping this Declaration constantly in mind, shall strive by teaching and education to promote respect for these rights and freedoms". In its English, French, and Spanish incarnations, the UDHR was adopted as Resolution 217 A (III) by unanimous vote (with eight abstentions, by five Soviet bloc nations plus Saudi Arabia and South Africa) on December 10, 1948. It immediately began proliferating throughout the planet - not only in the other official UN languages, Chinese and Russian; in Arabic, which became an official UN language in 1973; and in other widely spoken, government-sanctioned languages such as Bengali, Hindi, Japanese, and Portuguese; but also in stateless minority languages such as Aymara, Frisian, Hawaiian, Hmong, Mayan, Ojibwe, and Romani. The UDHR has been invoked explicitly in dozens of national constitutions adopted since 1948, as well as in hundreds of international treaties and conventions. It has also inspired the creation and continuing vigilance of such non-governmental organizations as Amnesty International and Human Rights Watch. Implicitly, and often explicitly, it has haunted the war crimes trial of Serbian leader Slobodan Milošević, the extended house arrest of Burmese dissident Aung San Suu Kyi, the persecution by the Chinese government of practitioners of Falun Gong, and the use of "extraordinary rendition" by American authorities against suspected terrorists.

\section{Discussion}

But the exceptionally wide diffusion of the UDHR challenges the document's ability to function as a common standard of achievement for all peoples and all nations. According to Talmudic legend, the Septuagint came into existence in the $3^{\text {rd }}$ century BCE when King Ptolemy II placed 72 scholars in 72 separate rooms and instructed them to produce a translation of the Hebrew Bible into Koine Greek. All 72 translations commissioned by Ptolemy were said to have been identical. An infinite number of monkeys with an 
infinite number of keyboards might eventually have tapped out those 72 identical iterations, but the Talmudic account (Tractate Megillah 9A) of the origins of the Septuagint seems as miraculous as the parting of the Red Sea. It is likely that even two translators working independently of each other would arrive at two distinct variants. The 523 versions of the UDHR have more in common with the childhood game of Telephone, in which a message is passed down a line of participants and changes dramatically during transmission.

When a text asserts authority, we naturally seek to identify the author. The United Nations is the collective author of the UDHR, and the individuals who rendered the text into each language have, for the most part, vanished into that invisibility that is traditionally the goal - or at least the fate - of the translator. In his history of translation, Lawrence Venuti identifies a spectrum between "domesticating" and "foreignizing" translations; and domesticating translations, those that do not call attention to their derivative status because their translators become invisible, are more common [1. P. 21]. For all their labor, few translators ever achieve fame or wealth. In only a very few instances does the web site for the UDHR, which provides links, in impartial alphabetical order, to each of the 523 versions, credit an individual translator. Philippe Blanchet, for one, is listed as responsible for putting the UDHR into Provencal. Asked which text he used as his source, he replied: "Both English and French, I also had a look at the Italian version for some details" . Pamela Munro is credited with both the Chickasaw and the San Lucas Quiavin Zapoteco texts, both of which she reports were derived from the English version. About the interchangeability of her translations with their source, she warns: “...there are different cultural conceptions of human rights. The UDHR is very much culturally anchored in Western postwar idealism"2.

Aside from a few examples such as those, almost all the other versions of the UDHR are attributed to organizations rather than individuals. The Wolof text is credited to the United Nations Information Centre, Senegal; the Urdu to the United Nations Information Centre, Pakistan; the Catalan to the United Nations Information Centre, Spain; and the Sanskrit to the United Nations Information Centre, India. Several other texts, including those in Albanian, Arabic, Armenian, Dutch, Filipino, Hindi, Sudanese, Telugu, and Tiv, are listed as having been supplied by the United Nations Information Centre, New York. Amnesty International UK is credited with creating versions of the UDHR in Chinanteco, Even, Gagauz, Sardinian, and Scots, while responsibility for the Esperanto version is assigned to Universala Esperanto Asocio in Rotterdam. The effect of these corporate attributions is to emphasize that the document was created by agencies and to deflect attention from the personal agency involved in choosing words from one language to substitute for those of another language. The institutional generation of the UDHR's multiple versions is a form of self-translation similar to what happens when translingual authors such as Samuel Beckett, André Brink, Isak Dinesen, Ariel Dorfman, and Vladimir Nabokov transpose their own writings into another language. And it reinforces the illusion that the UDHR is spread impartially and equally across 523 languages, as if the echt Declaration exists not in any single version but rather in the entirety of its iterations. We are led to believe that the sum total of this Babel is the consummate articulation of human

\footnotetext{
1 Philippe Blanchet. Email to the author. May 22, 2011.
}

2 Pamela Munro. Email to the author. May 19, 2011. 
rights. However, despite the institutional claims for parity, all the versions of the UDHR except those in the official UN languages (and probably even a few of those) are translations. And the existence of translations and sources, derivatives and originals, implies a hierarchy of authenticity and authority.

Defining and proclaiming inalienable rights was one of the first priorities of the nascent United Nations after its founding late in 1945. The task was delegated to committees set up by the UN Human Rights Commission, an agency of the UN Economic and Social Council. During most of the painstaking deliberations that consumed two years, the working title for the project was the International Declaration of Human Rights. That name eventually morphed into the United Nations Declaration of Human Rights. However, during the final stage of drafting, the French delegation, preferring to deflect attention from the sponsors of the Declaration to its beneficiaries, convinced their colleagues to change the document's title again, to what it has been known as since [2. P. 33]. The Universal Declaration of Human Rights might seem a solecism, an instance of misplaced modification. Surely, it is human rights that are universal, not the Declaration. Yet, even before the drafting process was complete, the United Nations Human Rights Commission was forced to defend its premise that certain rights are valid everywhere, independently of the milieux in which they are embedded.

In June, 1947, the executive board of the American Anthropological Association sent a preemptive letter to the Commission warning about ethnocentric presumptions in "a statement of rights conceived only in terms of the values prevalent in the countries of Western Europe and America” [3. P. 222]. While the drafting committee was wrestling with the wording of the UDHR, another UN agency, UNESCO, queried 150 prominent thinkers about whether it is indeed possible to identify any core values shared by all cultures. Among the respondents, who also included Benedetto Croce, Aldous Huxley, Richard McKeon, Salvador de Madariaga, and Pierre Teilhard de Chardin, Jacques Maritain was skeptical about finding common ground among widely diverse world views, noting that: "the ideological contrast is irreducible and no theoretical reconciliation is possible" [4. P. 183]. More interested in responsibilities than rights, Mohandas Gandhi stated: "I learned from my illiterate but very wise mother that all rights to be deserved came from duty well done" [4. P. 184]. Nevertheless, the UNESCO study concluded that, despite the fact that fundamental convictions throughout the world "are stated in terms of different philosophic principles and on the background of divergent political and economic systems" [3. P. 222], for practical purposes it is in fact possible to identify certain practices that are intolerably abhorrent in all human societies and others that elicit unanimous approbation.

Urging adoption of the document that she and others had been laboring over during more than eighty meetings in Europe and the United States, Eleanor Roosevelt, who chaired the UN Human Rights Commission, told the General Assembly that: "This Declaration may well become the international Magna Carta of all men everywhere. We hope its proclamation by the General Assembly will be an event comparable to the proclamation of the Declaration of the Rights of Man by the French people in 1789, the adoption of the Bill of Rights by the people of the United States, and the adoption of comparable declarations at different times in other countries" [3. P. 166]. However, the Magna Carta, the Déclaration des droits de l'Homme et du Citoyen, and the Bill of 
Rights form part of a very specific Western political tradition, one that the framers of the UDHR consciously tried, with varying degrees of success, to enlarge. They were sensitive to the accusation of slighting values from other cultures and assuming the universality of their own. They pointed to the fact that the drafting committee consisted of delegates from eight farflung nations - Australia, Chile, China, France, Lebanon, the Soviet Union, United Kingdom, and United States - and that many of the 50 other nations that in 1948 constituted the United Nations provided significant input into the 30 articles adopted as the final document. In 1993, forty-five years after its adoption, when 171 nations met in Vienna to reaffirm their commitment to the core principles of the UDHR, their official communiqué proclaimed: "The universal nature of these rights and freedoms is beyond question" (Vienna Declaration and Programme of Action, World Conference on Human Rights, 1993. Retrieved May, 2011 from: http://www.fao.org/righttofood/ $\mathrm{KC} /$ downloads/vl/docs/AG889.pdf.). Yet questions have in fact been raised from the very beginning, despite conscientious attempts to paper over political and linguistic discrepancies. The question of whether there are indeed cultural universals parallels the question of whether there are linguistic ones. A belief that human rights transcend the attitudes and mores of specific societies is not dissimilar from a Chomskyan conviction that deep structures common to all human languages are more significant than superficial differences in morphology, syntax, and phonology. Universal, the floating modifier in the Universal Declaration of Human Rights, points to its premise that both rights and writing transcend place and time.

Intent on demonstrating how international and conscientious the project of creating the UDHR was, Charles Habib Malik, the delegate from Lebanon and a key figure during the drafting process, observed that: "It may be that no other document in history, of the importance of the Universal Declaration, received the same world-wide, sustained consideration and scrutiny that this document did" [5. P. 19]. Elsewhere, he recalled that "...every word and comma and semicolon was gone over most carefully several times by the chancelleries and representatives of some fifty-eight governments..." [6. P. 275]. However, precision in punctuation could not guarantee linguistic homology. English and French were the working languages of the committees that hammered out the wording of the UDHR, though Chinese, Russian, and Spanish were also at the time official languages of the UN. A month before the Declaration - in English, French, and Spanish texts - was submitted to a vote of the General Assembly, a subcommittee appointed at Malik's initiative was established "to ensure exact correspondence of the text in the five official languages of the UN" [7. P. 163]. Of course, there can be no exact correspondence between Chinese and Russian or even between French and Spanish, and adding languages beyond those five has meant multiplying discrepancies. As Christopher Kuner notes, "The presumption of similar meaning is nothing more than a rule of convenience designed to reconcile the practice of providing authentic versions of treaties in as many as five or six languages with the general unwillingness to interpret treaties in a truly multilingual fashion" [8. P. 962].

In international relations as in poetry, translation is indeed betrayal, if unavoidable. The initial draft of the UDHR was prepared by John Peters Humphrey, a legal scholar from Canada who served as head of the UN Secretariat on Human Rights. Though bilingual in English and French, he worked primarily in English. Humphrey's draft was 
revised by René Cassin, a prominent French jurist whose command of English was shaky. He confessed in his memoir that, confused over what was being said during one meeting, he inadvertently voted in favor of a measure he actually opposed: "I failed to understand, and thus let pass, proposals and resolutions that did not correspond to my own views" [4. P. 196].

Neither English nor French was a problem for the Lebanese Malik, a philosopher who had written his doctoral dissertation under Alfred North Whitehead at Harvard University and later taught at the American University of Beirut. Nor was it for the drafting committee's vice chairman, Peng-chun Chang, the Chinese delegate who had earned his Ph.D. under John Dewey at Columbia University. The Indian delegate, Hansa Mehta, had translated Hamlet, The Merchant of Venice, and Gulliver's Travels, as well as Le Bourgeois Gentilhomme and Tartuffe, into Gujarati. Carlos P. Rómulo, the delegate from the Philippines, had earned an M.A. from Columbia University, served as chairman of the Department of English at the University of the Philippines, and received a Pulitzer Prize for his English-language journalism. Eleanor Roosevelt, who patiently and deftly guided the UDHR from conception to adoption, was of course, like William Hodgson of Australia and Charles Dukes of the United Kingdom, an Anglophone. However, she was fluent enough in French that once, when Cassin spoke so long without pausing for translation that the interpreter left the room in tears, she was able to provide an English summary of his speech [3. P. 31]. Of the core members of the drafting team, only Hernán Santa Cruz, of Chile, and Alexei Pavlov, of the Soviet Union, might have had to rely on translators to understand and be understood during the course of the proceedings.

The specific choice of words in a UN text is a matter of more than merely stylistic interest. A statement on human rights created and endorsed by the world body has reallife implications and consequences. Nevertheless, anxious not to get bogged down further in disputes over definition and jurisdiction, the framers of the UDHR agreed to defer questions of implementation and enforcement. The visionary document that the UN adopted in 1948 was designed to provide a set of guiding principles for all people for all time. It is not legally binding the way that the UN Covenant on Civil and Political Rights and the UN Covenant on Economic, Social, and Cultural Rights, both ratified in 1976, are, but it has had a wider influence through its moral force, as "a common standard of achievement for all peoples and all nations". Beyond its widespread incorporation into subsequent national and international law, the UDHR has inspired millions throughout this imperfect world with a forthright statement of how things ought to be. The framers aimed for lucidity and economy, and most accounts of the drafting of the UDHR discuss the language of the document not in terms of the incommensurability of Italian, Persian, and Thai but rather in terms of how, aiming for precision, concision, and simplicity, delegates fretted over their choice of words, subjecting parts of the document to 1400 separate committee votes before the General Assembly finally adopted it in toto. Alert to redundancies, the architects of the UDHR pared the 49 articles in Humphrey's first draft down to 30 in the final version. Most agreed with Chang that the Declaration "should be as simple as possible and in a form which was easy to grasp" [2. P. 34]. Though article 46 in the Humphrey draft, which guaranteed the right to expression, education, and litigation in an individual's own language, disappeared from later versions, its principle 
of linguistic equality was assumed to be implicit in the rest of the document. And language as the medium of the UDHR itself was never far from the deliberations.

Some friction among the drafters over the wording of rights was ideological rather than linguistic, though the English word right does not translate perfectly into the Russian

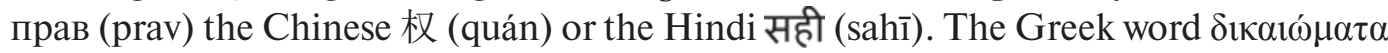
(dikaiómata) and זכויות (zkhuyot), the Hebrew word, lack any authoritative association with the dominant right hand found in the words rights, droits, derechos, Rechte. Western delegates, heirs to an Enlightenment emphasis on the individual as an independent moral agent, were most intent on affirming civil and political principles (freedom of speech, assembly, and belief, presumption of innocence), while delegates from the Soviet bloc and Latin America emphasized economic and social ones (the right to employment, education, health care, and housing). Franklin D. Roosevelt's 1941 "Four Freedoms" speech, proclaiming freedom of expression and belief as well as freedom from want and fear, provided a basis for consensus, and the UDHR ended up accommodating both libertarian and communitarian orientations toward rights. Disagreement over the wording of religious rights focused on the possibility of conversion. To the Muslim member of the commitee, Article 18's guarantee of the freedom to switch religions translated into Arabic not as a freedom but as ردة (murtad), apostasy. That and Article 16's guarantee of equal rights in marriage led Saudi Arabia to abstain on the final vote to adopt the document.

During discussion of Article 2's insistence that everyone, without distinction, is entitled to the rights set forth in the Declaration, M.H. Klevkovkin, the Ukrainian delegate, recommended specifying that those rights apply regardless of social status. He suggested inserting the term сословие (sosloviye), a Ukrainian and Russian word meaning, roughly, "estate". However, because historical Eastern European social categories do not translate easily into other languages сословие did not make it into the final draft, which guarantees human rights regardless of "race, colour, sex, language, religion, political or other opinion, national or social origin, property, birth or other status". A variant of сословие does show up in the Russian version, but not in the Ukrainian.

Article 4, which prohibits slavery, originally stated that: "No one shall be held in slavery or involuntary servitude", though the French version simply stated: "Nul ne sera... tenu en servitude", omitting the adjective "involontaire" [9. P. 103]. When A.F. Canas, the delegate from Costa Rica, pointed out the discrepancy, Cassin observed that in French all servitude is involuntary. Though in English it is possible to describe certain military and occupational commitments as "voluntary servitude", the phrase "involuntary servitude", Cassin insisted, does not have any meaning in French. To repair this disparity between the English and French texts, the committee voted 17-15, with 4 abstentions, to delete the word "involuntary" from the final English text.

The English version of Article 12, guaranteeing that: "No one shall be subjected to arbitrary interference with his privacy", was rendered into French as "Nul ne sera l'objet d'immixtions arbitraires dans sa vie privée", into Spanish as "Nadie será objeto de injerencias arbitrarias en su vida privada", and into German as "Niemand darf willkürlichen Eingriffen in sein Privatleben". However, some communal cultures do not value or even recognize privacy, and their languages lack a term to denote it. Russian possesses no satsifactory equivalent for privacy, vie privée, vida privada, or Privatleben, and its version of Article 12, “Никто не может подвергаться произвольному вмешательству в его 
личную...”, instead affirms the protection of the personal (личную, lichnuyu), which is not quite the same as privacy.

It is possible to go through the entirety of the Declaration, from the Preamble to the conclusion of Article 30, noting divergences created by the fact that no two languages are identical. However, a glance at Article 1, a statement of the fundamental premises on which the entire document is based, might suffice for a sense of how cacophonous is the polyglot polytext that the United Nations sent off into the world. The draft that Cassin submitted in June, 1947 begins: "Tous les hommes sont frères. Comme êtres doués de raison et membres d'une seule famille, ils sont libres et sont égaux en dignité et en droits". He was clearly borrowing from the 1789 Déclaration des droits de l'Homme et du Citoyen, whose first article begins: "Les hommes naissent et demeurent libres et égaux en droits". ("Men are born and remain free and equal in rights". The English rendition of Cassin's text submitted to the committee was: "All men, being members of one family are free, possess equal dignity and rights, and shall regard each other as brothers".) In French, English, Spanish, and many other European languages, "men" can function as synecdoche for "human beings", though since 1948 it has grown increasingly suspect as sexist. However, a Soviet delegate, Vladimir Koretzsky, objected, contending that the phrase "All men" is one of those "historical atavisms which preclude us from an understanding that we men are only one-half of the human species" [3. P. 68]. Although she called herself a feminist, Roosevelt defended the commonplace conflation of "men" with "human beings". After considerable discussion, the drafting committee eliminated the masculine subject, making the opening of Article 1 read: "Tous les êtres humains naissent libres et égaux en dignité et en droits" / "All human beings are born free and equal in dignity and rights". Nevertheless, in Basque, it is necessary to distinguish between male and female, and, instead of making the subject of the sentence in Article 1 generic, the Basque version of the UDHR had to substitute a compound subject: "Gizon-emakume guztiak aske jaiotzen dira" (All men and women are born free). The second sentence of Article 1 still calls for "a spirit of brotherhood", and the French version, echoing the revolutionary call for liberté, égalité, et fraternité, similarly demands a spirit of fraternité. The German רוח version likewise refers to Geiste der Brüderlichkeit and the Hebrew to של אחווה.

Again avoiding a masculine bias, the Basque version calls for all human beings to behave toward one another artean senide - as if within the family. One hopes that Basque families are not abusive. The name of the entire document - in English, the Universal Declaration of Human Rights; in Spanish, la Declaración Universal de Derechos Humanos; in Russian, Всеобщую декларацию прав человека; in Chinese, 世界人权 宣言; and in Arabic الاعـلان العـالمي لحقــوق الانســان. - is generic, but the French version, la Déclaration universelle des droits de l'homme, is not. It echoes the hallowed Déclaration des droits de l'Homme et du Citoyen and demonstrates how, even if their syntax and vocabularies are similar, languages bear different historical freight.

Similarly, inclusion of the word dignity in the English version of Article 1 is probably a vestige, if not a calque, from the French Déclaration des droits de l'Homme et du Citoyen, which, against the crushing power of Bourbon monarchy, proclaimed la dignité of ordinary individuals; as much as the nobility, they, too, are digne de (worthy of) moral consideration. The English version of Article 1 might have done better to assert that all 
human beings are equal in worth or value, since the word dignity in English evokes the fusty image of starched collars and walking sticks. Surely the UDHR is not intended as an accessory to vanity or as a prohibition against satirists such as Jon Stewart from deflating the self-esteem of the sanctimonious and the hypocritical. Nor is dignity exactly commensurate with Würde, $\alpha \xi_{10} л \rho \varepsilon ́ \pi \varepsilon ı \alpha$ (axioprépeia), dignidade, waardigheid, or достоинства (dostoinstva).

Chang, the vice chairman of the drafting committee, suggested inserting the Chinese word 仁 (rén) into Article 1. He explained that, as a combination of the characters 人 (man) and 二 (two), it meant something like "two man-mindedness" [3. P. 67]. Its English equivalent might be empathy. However, the commission instead ended up asserting that human beings are endowed not with 仁, but with reason and conscience, terms that are themselves each problematic in English and possess imprecise equivalents in other languages. The French text also employs the word conscience (just as the Spanish text uses conciencia and the Italian coscienza), but the meaning is somewhat different in the Romance languages, closer to consciousness. Nor did 仁 (rén) make it into the final Chinese version, which employs the term 良心 (liángxīn) instead. 良 心 (liángxīn) is usually rendered in English as conscience.

While it is the most ambitious, the UDHR is certainly not the earliest instance of a transnational plurilingual text. Versions of a peace treaty that ended hostilities between the Egyptian Pharoah Ramesses II and the Hittite King Hattušiliš III in 1271 B.C.E. have been preserved in both Egyptian hieroglyphics and Hittite cuneiform [10. P. 23]. According to the Book of Esther (3:12), when Haman determined to exterminate all the Jews in the polyglot Persian empire, he prepared an edict in the name of King Ahasuerus and dispatched it "to every province according to the writing thereof, and to every people after their language". Ahasuerus rescinded the death decree by sending out countermanding orders in each of those same languages (8:9). The Treaty of Versailles that concluded World War I was drafted simultaneously in French and English and taken to possess primary and equal authority in each. In 1969, as linguistically parallel versions of international agreements were multiplying, the Vienna Convention on the Law of Treaties attempted to codify their status in international law. Article 1 of the Vienna Convention states that: "When a treaty has been authenticated in two or more languages, the text is equally authoritative in each language, unless the treaty provides or the parties agree that, in case of divergence, a particular text shall prevail" [8. P. 454 n. 5]. That has not silenced controversy among legal scholars about whether, in applying plurilingual documents to particular situations, one text is sufficient or it is necessary to consider all authoritative linguistic versions. Furthermore, ascribing authority is one thing, but Article 3 of the Vienna Convention goes on to make the preposterous claim that: "The terms of the treaty are presumed to have the same meaning in each authentic text”. The Unnamable (1958) could not possibly have the same meaning as L'Innomable (1953), even if Beckett had attempted to make his English text a perfect facsimile of his French novel. It is as naive to assume perfect congruence between the English and Russian texts of the Nuclear Non-Proliferation Treaty ("the English, Russian, French, Spanish, and Chinese texts of which", according to its Article XI, "are equally authentic") as between Lolita and Лoлита, even if Nabokov had not consciously reconceived his novel between its publication in English in 1955 and in Russian in 1967. 
When they were signed in Uccialli in 1889, it was agreed that the Amharic and Italian versions of the Treaty of Friendship and Commerce between Italy and Ethiopia possessed equal authority [11. P. 5]. In Amharic, Article 17 stated that Emperor Menelik II was permitted to use the services of the Italian government to conduct foreign relations. However, when the emperor discovered that the Italian text stated that he was obliged to use the services of the Italian government to conduct foreign relations, he was furious at the attempt to erase Ethiopia's sovereignty through linguistic legerdemain. By 1896, the discrepancy between the two texts had led to a war in which Italian troops suffered more than 5,000 casualties. Because the Italian and Amharic texts were incompatible, Italy was eventually forced to pay an indemnity of 10 million lire and to renounce, in no uncertain terms, any claims to Ethiopian territory. Similarly, many years after the conclusion of the 1967 Six Day War, contemporary tensions in the Middle East remain exacerbated by the fact that the two authoritative versions of United Nations Security Council Resolution 242 do not say quite the same thing. Israel has accepted the English wording of Article 1, which calls for: "Withdrawal of Israel armed forces from territories occupied in the recent conflict". However, the government of the state of Israel rejects the French text, which calls for "retrait des forces armées israéliennes des territoires occupés lors du récent conflit" (withdrawal of Israeli armed forces from the territories occupied in the recent conflict). Because French, unlike English, requires an article or a partitive before a noun, it was impossible to use the phrase "retrait de forces armées israéliennes des territoires occupés lors du récent conflit". But because "retrait des forces armées israéliennes des territoires" could mean withdrawal from the (i.e. all the) territories, Israeli officials found the resolution acceptable only in its vaguer English wording.

Belgium, Canada, India, South Africa, and Switzerland are among contemporary nations that recognize multiple official languages and generate legally binding, parallel texts in each. But the closest analogy to the linguistic pluralism of the UDHR is probably found in the Official Journal of the European Union. Published every working day at considerable expense, the Journal appears in identical formats in each of the official languages of the European Union. At present, the EU certifies 23 languages as "official and working" (English, French, and German are the "procedural languages" of the European Commission), with more likely to come as its membership expands to include such nations as Albania, Iceland, and Turkey. However, even if the EU ends up having to employ translators to cover as many as 30 languages, its purposes would still seem modest in comparison to those of the UDHR, which aspires to speak about essential things to everyone everywhere.

The Universal Declaration of Human Rights imagines an ideal planet in which hunger, torture, homelessness, unemployment, arbitrary arrest, exploitation, and tyranny do not exist. It projects a utopian vision of the best of all possible worlds created in reaction to a global crisis in which the worst were filled with passionate intensity and the best floundered in the absence of an international mechanism to prevent unprecedented carnage. Of necessity, as a proclamation of general principles, the UDHR abounds with abstract terms such as freedom, liberty, dignity, justice, equality, and rights, all of which are problematic within just English and impossible to find exact equivalents of in other languages. Philippe Blanchet, who struggled to translate the lofty French and English of the document into Provencal, a language that favors concreteness, in fact noted that: 
"... we don't express things in abstract terms in Proven al and ... I had to try and find a way to turn it into a more pragmatic and familiar way of saying it, which is very important in the Proven al culture and sociolinguistics rules". Not only did he find it difficult to represent the abstractions in the Declaration, but he reports that Provencal concepts such as lou parage, which means the condition of living together as equal beings, simply have no equivalent in French and English (Blanchet, personal correspondence).

Moreover, the UDHR adopts the European Enlightenment model of personhood, of the individual human being as a rational, sovereign moral agent. Rights do not exist unless they can be asserted, and they cannot be asserted if they are not articulated. Using the tools of distinct first-, second-, and third-person pronouns as well as the ascription of causality through subject-verb agreement, English and French are efficient mechanisms for delineating the kinds of human rights that did not exist under fascism. Might different linguistic systems in the Amazon rain forest and Papua New Guinea express human relationships very differently? Of course, it is a truism of anthropology that human relationships vary considerably from culture to culture, and a key to all cultures might seem chimerical, attained not empirically but mystically. However, in the first chapter of De Interpretatione, Aristotle contends that "affections of the soul" are universal, though expressed differently in different languages. For Roosevelt and the other members of the committee convened by the UN after World War II, human rights were indeed "affections of the soul", and if a common language does not exist in which to express them, we must stretch all the languages we have to accommodate discourse about rights. An opponent of essentialism, John Rawls, would deny a universal core to human rights, positing instead "an overlapping consensus" [12. P. 421].

\section{Conclusion}

However, in order to understand that overlap, we still need a shared language. And if there is indeed an overlap, we might as well call it universal. The cosmopolis of perfect communication in which every human being is accorded respect persists as a fond fantasy.

The task of the translator is, according to Walter Benjamin's famous essay by that name, to aim to attain the impossible, a pure language that is the consummation of the thousands of actual human tongues. "It is the task of the translator", he wrote, "to release in his own language that pure language which is exiled among alien tongues, to liberate the language imprisoned in a work in his re-creation of that work. For the sake of the pure language, he breaks through decayed barriers of his own language" [13]. There may or may not be a Universal Grammar - of human rights or of human language. But each of the 523 versions of the Universal Declaration of Human Rights aspires to that ideal language and ideal human condition for which we still lack perfect words.

\section{References}

1. Venuti, L. 1995. The Translator's Invisibility: A History of Translation. New York: Routledge. Print.

2. Morsink, J. 1999. The Universal Declaration of Human Rights: Origins, Drafting, and Intent. Philadelphia, University of Pennsylvania Press. Print.

3. Glendon, M.A. 2001. A World Made New: Eleanor Roosevelt and the Universal Declaration of Human Rights. New York: Random House. Print. 
4. Normand, R., and S. Zaidi. 2008. Human Rights at the UN: The Political History of Universal Justice. Bloomington: Indiana University Press. Print.

5. Malik, Ch. 1978. "The Drafting of the Universal Declaration of Human Rights". United Nations Bulletin of Human Rights 86 (1): 18-26.

6. Malik, Ch. 1951. "Human Rights in the United Nations". International Journal 6 (4): 275-80.

7. Alfredsson, G., and A. Eide. 1999. The Universal Declaration of Human Rights: A Common Standard of Achievement. Kluwer Law International: The Hague. Print.

8. Kuner, Ch. 1991. "The Interpretation of Multilingual Treaties: Comparison of Texas versus the Presumption of Similar Meaning". International and Comparative Law Quarterly 40 (4): 953-64.

9. Verdoodt, A. 1963. Naissance et signification de la Déclaration Universelle des Droits de l'Homme. Louvain-Paris: Nauwelaerts. Print.

10. Šarčević, S. 1997. New Approach to Legal Translation. The Hague: Kluwer Law International. Print.

11. Tabory, M. 1980. Multilingualism in International Law and Institutions. Alphen aan der Rijn: Sijthoff \& Noordhoff. Print.

12. Rawls, J. 1999. "The Idea of an Overlapping Consensus". Collected Papers. Ed. Samuel Freeman. Cambridge, MA: Harvard University Press. Pp. 421-448. Print.

13. Benjamin, W. 1996. Selected Writings: Volume 1, 1913-1926. Ed. Marcus Bullock and Michael W. Jennings. Cambridge: Harvard University Press. Print.

\section{Bio Note:}

Steven G. Kellman is a Professor at the Department of English, University of Texas at San Antonio, USA. E-mail: steven.kellman@utsa.edu

\section{Сведения об авторе:}

Келлман Стивен - профессор Департамента английского языка Техасского университета Сан-Антонио,США. E-mail: steven.kellman@utsa.edu 